\title{
Article
}

\section{An Engineered Multimodular Enzybiotic against Methicillin-Resistant Staphylococcus aureus}

\author{
Salim Manoharadas 1,2,*(D), Mohammad Altaf ${ }^{2,3}$, Abdulwahed Fahad Alrefaei 4 (D), Naushad Ahmad 2,3, \\ Shaik Althaf Hussain ${ }^{2,4}$ and Basel F. Al-Rayes ${ }^{2}$ \\ 1 Department of Botany and Microbiology, College of Science, King Saud University, P.O. Box 2454, \\ Riyadh 11451, Saudi Arabia \\ 2 Central Laboratory RM 63AA, College of Science, King Saud University, P.O. Box 2454, \\ Riyadh 11451, Saudi Arabia; maltaf@ksu.edu.sa (M.A.); anaushad@ksu.edu.sa (N.A.); \\ salthaf@ksu.edu.sa (S.A.H.); bfalrayes@ksu.edu.sa (B.F.A.-R.) \\ 3 Department of Chemistry, College of Science, King Saud University, P.O. Box 2454, \\ Riyadh 11451, Saudi Arabia \\ 4 Department of Zoology, College of Science, King Saud University, P.O. Box 2454, Riyadh 11451, Saudi Arabia; \\ afrefaei@ksu.edu.sa \\ * Correspondence: smanoharadas@ksu.edu.sa; Tel.: +966-114689170
}

Citation: Manoharadas, S.; Altaf, M.; Alrefaei, A.F.; Ahmad, N.; Althaf Hussain, S.; Al-Rayes, B.F. An Engineered Multimodular Enzybiotic against Methicillin-Resistant Staphylococcus aureus. Life 2021, 11, 1384. https://doi.org/10.3390/ life11121384

Academic Editor: Milan Kolář

Received: 8 November 2021 Accepted: 8 December 2021 Published: 10 December 2021

Publisher's Note: MDPI stays neutral with regard to jurisdictional claims in published maps and institutional affiliations.

Copyright: (c) 2021 by the authors. Licensee MDPI, Basel, Switzerland. This article is an open access article distributed under the terms and conditions of the Creative Commons Attribution (CC BY) license (https:// creativecommons.org/licenses/by/ $4.0 /)$.

\begin{abstract}
Development of multidrug antibiotic resistance in bacteria is a predicament encountered worldwide. Researchers are in a constant hunt to develop effective antimicrobial agents to counter these dreadful pathogenic bacteria. Here we describe a chimerically engineered multimodular enzybiotic to treat a clinical isolate of methicillin-resistant Staphylococcus aureus (S. aureus). The cell wall binding domain of phage $\phi 11$ endolysin was replaced with a truncated and more potent cell wall binding domain from a completely unrelated protein from a different phage. The engineered enzybiotic showed strong activity against clinically relevant methicillin-resistant Staphylococcus aureus. In spite of a multimodular peptidoglycan cleaving catalytic domain, the engineered enzybiotic could not exhibit its activity against a veterinary isolate of $S$. aureus. Our studies point out that novel antimicrobial proteins can be genetically engineered. Moreover, the cell wall binding domain of the engineered protein is indispensable for a strong binding and stability of the proteins.
\end{abstract}

Keywords: enzybiotics; bacteriophage; MRSA; antibiotic-resistant bacteria; Staphylococcus aureus

\section{Introduction}

Multidrug-resistant pathogens cause a serious threat to the health of both humans and animals. More than two million people are infected every year with conventional antibiotic-resistant bacteria in the United States alone [1]. Besides the fact of antibiotic resistance development, there is a problem of non-specific damage that the conventional antibiotics cause to commensal microbes, hence causing long-term harmful effects like secondary infections, obesity, asthma, and type I and II diabetes [2-5]. Therefore, it is an absolute necessity to develop specific therapeutics to target drug-resistant pathogens, without affecting the commensal microbiota. There is a new class of enzyme-based antibacterials, known as enzybiotics that could potentially replace antibiotics in the near future. Enzybiotics are generally safe, fast acting, highly specific and effective. In addition, there is a low probability of the development of bacterial resistance to enzybiotics. Furthermore, it has been shown that enzybiotics can be used alone or in combination with traditional antibiotics, generally reducing the effective concentration of the antibiotics [1,6]. Enzybiotics are generally derived from bacteriophage endolysins, which lyse the bacterial cells at the end of the lytic replicative cycle, facilitating the release of phage progenies. This feature of the endolysin has been exploited to kill Gram-positive pathogens, when added exogenously [7]. It has been shown that the exogenous addition of recombinant enzybiotics induces rapid osmotic lysis of Gram-positive bacteria, primarily through the 
degradation of accessible peptidoglycan. In vivo efficiency of various enzybiotics has been shown in animal models of human disease [7-10]. Recent studies have also pointed out that enzybiotics are effective against MRSA strains in wound infections [11]. In addition to wound infections, enzybiotics have also been shown to penetrate cells and eradicate intracellular antibiotic-resistant $S$. aureus pathogens [12].

Apart from the studies of enzybiotics on the treatment of pathogenic bacteria, enzybiotics have also been successfully used for food bio-preservation [13]. This is particularly important as multidrug-resistant bacteria can reach the food supply chain from farm to postharvest and processing such as fermentation, slaughtering, packaging and storage [14-16]. Another study where enzybiotics have been successfully used was in orthopedic device-related infections (ODRI) [17]. The most common bacteria associated with bone-related infections is the Staphylococcus species with an infection rate of $\sim 66 \%[18,19]$. The prevalence of MRSA often complicates the situation with biofilm formation on the surgical implants [20,21]. Two enzybiotics, M23 and GH15, were efficient in killing both planktonic and biofilm encased S. aureus strains associated with ODRI [17].

There are marked advantages of engineering enzybiotics against pathogenic bacteria. The engineering of enzybiotics, typically by replacing the cell wall binding domain making the lysin active against a larger number of bacterial strains. Apart from this, engineered enzybiotics also behave differently in comparison with their non-engineered counterparts. For instance, the natural endolysin (Pal) of the pneumococcal phage Dp-1 was show to be of intergeneric origin and displayed activity against Gram-positive bacteria [22]. However, part of the lysin was used for creating an engineered enzybiotic, known as artilysins. The engineered enzybiotic was able to lyze Gram-negative bacteria also in addition to Grampositive bacteria $[23,24]$. The development of novel chimeric enzybiotics also provides help to determine the molecular evolution of genes. $[25,26]$. A detailed review was published in 2018 regarding the strategies employed and advantages of engineered phage-derived lytic enzymes in comparison to their parental counterparts [27].

In this study we investigated the antimicrobial potential of a chimeric enzybiotic against $S$. aureus including the clinical MRSA strain. Our idea was to compare the antimicrobial efficiency of two proteins, CA and CA100. Protein CA encompassed the CHAP and amidase residues from the $S$. aureus phage $\phi 11$ without the cell wall binding domain. CA100 on the other hand harbored the CHAP and amidase domain in the N-terminal and part of the cell wall binding domain from protein P17 from the S. aureus phage $\phi 44 \mathrm{AHJD}$. We tested the antimicrobial efficiency of both the proteins on three S. aureus strains: S. aureus $8325-4$, clinical MRSA and S. aureus Rumba, a veterinary isolate. Our data suggest that newer, effective enzybiotics can be developed by replacing the native cell wall binding domain.

\section{Materials and Methods}

\subsection{Bacterial Strains and Bacteriophages}

The S. aureus strain Rumba, S. aureus 8325-4, clinical MRSA and E. coli strain KKH001 were used to study the effectiveness of the proteins. The S. aureus strain Rumba was a veterinary isolate from the udder of a cow named 'Rumba' with bovine mastitis. Clinical MRSA was obtained from King Khalid Hospital \& Prince Sultan Center for Health Care, Al Kharj, Saudi Arabia. S. aureus 8325-4 is a routinely used lab strain. E. coli strain KKH001 was collected from Al Dawadmi General Hospital, Al Dawadmi, Saudi Arabia. S. aureus RN4220 was used for the propagation of phage $\phi 11$ and S. aureus B68 was used for the propagation of phage $\$ 44$ AHJD. S. aureus B68, S. aureus Rumba and phage $\$ 44$ AHJD was a gift from Prof. Dr. Udo Blaesi, MFPL, Vienna, Austria. S. aureus RN4220 and phage $\phi 11$ was a gift from Prof. Dr. Andreas Peschel, Universität Tübingen, Germany.

\subsection{Growth of Bacteria and Bacteriophages}

The bacteria were grown in LB media/agar ( $1 \%$ peptone, $1 \% \mathrm{NaCl}, 0.5 \%$ yeast extract, Micromaster, Thane, Maharashtra, India) $\mathrm{pH}$ : 7.0. The bacteria were grown at $37^{\circ} \mathrm{C}$ 
under shaking conditions (160 rpm) in an orbital shaking incubator until unless otherwise mentioned. For the propagation of bacteriophages, $50 \mu \mathrm{L}$ of $1 \times 10^{7}$ plaque-forming unit (PFU) of phage was added to $500 \mathrm{~mL}$ of corresponding host bacterial strain grown until an $\mathrm{OD}_{600}$ of 0.5 . The phage-added bacterial culture was incubated for further $5 \mathrm{~h}$ at $37^{\circ} \mathrm{C}$, under shaking conditions. The culture was centrifuged at $12,000 \mathrm{rpm}$ for $30 \mathrm{~m}$ at $4{ }^{\circ} \mathrm{C}$ to remove unaffected bacteria and debris. The enumeration of bacteriophage by plaqueforming unit assay was performed according to the standard protocol [28]. The supernatant was stored at $4{ }^{\circ} \mathrm{C}$ until further use.

\subsection{Extraction of Phage DNA and PCR Amplification of Genes}

The phage DNA was extracted according to the protocol described by [29] with modifications. Briefly, the phage was mixed with host bacteria and poured on an LB plate with top agar $\left(0.75 \%\right.$ agar), and the plates were incubated at $37^{\circ} \mathrm{C}$, overnight. The concentration of phage used was fixed as to produce a confluent lysis of the host bacterium. Five $\mathrm{mL}$ of SM buffer $\left(0.58 \% \mathrm{NaCl}, 0.2 \% \mathrm{MgSO}_{4} \cdot 6 \mathrm{H}_{2} \mathrm{O}, 5 \mathrm{~mL}\right.$ of $1 \mathrm{M}$ Tris- $\left.\mathrm{Cl} \mathrm{pH} 7.5\right)$ was added onto the plate and the plate was incubated at $4{ }^{\circ} \mathrm{C}$, overnight to elute phages from the top layer. After recovery, the mixture was centrifuged at $5000 \mathrm{rpm}$ for $5 \mathrm{~m}$ and the supernatant was filtered over $0.22 \mu \mathrm{M}$ filter. Five hundred $\mu \mathrm{L}$ of the lysate was treated with $1 \mu \mathrm{L}$ of DNase I ( $1 \mathrm{U} / \mu \mathrm{L}$, Fermentas, Waltham, MA, USA) and $1 \mu \mathrm{L}$ RNase A $(10 \mathrm{mg} / \mathrm{mL}$, Fermentas, Waltham, MA, USA) for $1.5 \mathrm{~h}$ at $37^{\circ} \mathrm{C}$. The reaction was stopped by adding $20 \mu \mathrm{L}$ of $0.5 \mathrm{M}$ EDTA (Fluka, Muskegon, MI, USA). The phage protein capsid was digested with, $1.25 \mu \mathrm{L}$ of Proteinase K (20 mg/mL Fermentas, Waltham, MA, USA) followed by incubation at $56^{\circ} \mathrm{C}$ for $1.5 \mathrm{~h}$. The phage DNA was precipitated with $99 \%$ ethanol at $-70{ }^{\circ} \mathrm{C}$, overnight, followed by wash with $70 \%$ ethanol. The pellet was air dried and resuspended in autoclaved distilled water.

The primers used for the amplification of $C A$ and $C A 100$ are listed in Table 1. A $2 \times$ Pfu mastermix (G-Biosciences, St. Louis, MO, USA) was used for the amplification of the genes. The genes were amplified using the conditions as shown $\left(94{ }^{\circ} \mathrm{C}\right.$ for $7 \mathrm{~m}, 94{ }^{\circ} \mathrm{C}$ for $1 \mathrm{~m}$, $62{ }^{\circ} \mathrm{C}$ for $30 \mathrm{~s}, 72{ }^{\circ} \mathrm{C}$ for $1.5 \mathrm{~m}, 72{ }^{\circ} \mathrm{C}$ for $7 \mathrm{~m}$ ). The PCR was allowed to run for 35 cycles. The PCR amplified product was checked on a $1 \%$ agarose gel and the size of the products were determined.

Table 1. Primers and plasmids used in this study.

\begin{tabular}{|c|c|c|}
\hline Gene Amplified & Primer Sequences & Size (bp) \\
\hline CHAP-amidase & Forward primer: 5'CTCAAGGATCCATGCAAGCAAAATTAACT3' & 1050 \\
\hline CHAP-amidase & Reverse primer: 5'CATAGGTACCGTAGTCTTTAAGTTGCAACC3' & 1050 \\
\hline CBD100 & Forward primer: 5'CATAGGTACCATCAAAACTGACGCACCATAT3' & 300 \\
\hline CBD100 & Reverse primer: 5'CAGGAAGCTTCTATTTTTGATGTTTTGCTACC3' & 300 \\
\hline Plasmid name & Notes on the plasmid & Synthesized protein upon IPTG induction \\
\hline pQE30 & $\begin{array}{l}\text { Expression vector. Lac promoter induced with IPTG. Synthesized } \\
\text { proteins have a 6X His-tag for purification. }\end{array}$ & NA \\
\hline PQE-CA & $\begin{array}{l}\text { The CHAP-amidase gene from phage } \phi 11 \text { cloned as BamHI/KpnI into } \\
\text { pQE30 vector. }\end{array}$ & $\begin{array}{l}\text { CHAP-amidase } \\
38 \mathrm{kDa}\end{array}$ \\
\hline pQE-CA100 & $\begin{array}{c}\text { The } 300 \mathrm{bp} \text { cell wall binding gene from protein } 17 \text { of phage } \phi 44 \mathrm{AHJD} \\
\text { was cloned as KpnI/HindIII into pQE-CA. }\end{array}$ & $\begin{array}{l}\text { CHAP-amidase }+ \text { Cell wall binding domain. } \\
\qquad 41 \mathrm{kDa}\end{array}$ \\
\hline
\end{tabular}

\subsection{Cloning and Expression of Genes}

The PCR amplification of gene CHAP-amidase was performed using primers 1 and 2 (Table 1). The PCR fragment was restricted with BamHI/KpnI and was cloned into the expression vector $\mathrm{pQE30}$, restricted with BamHI/KpnI hence creating the plasmid pQE-CA. The $300 \mathrm{bp}$ cell wall binding gene fragment from gene 17 of phage $\phi 44 \mathrm{AHJD}$ was amplified with primers 1 and 3 (Table 1) and was restricted with KpnI/HindIII. The restricted fragment was cloned downstream of gene CHAP-amidase in the vector $\mathrm{PQE}-\mathrm{CA}$, creating the plasmid pQE30-CA100. The cloned genes were confirmed by sequencing to rule out any possibility of mutations. The cloned genes in PQE-CA and PQE-CA100 were 
induced by $0.5 \mathrm{mM}$ IPTG after growing the bacterial strain BL21 DE3 to an $\mathrm{OD}_{600}$ of 0.5 at $22{ }^{\circ} \mathrm{C}$, under shaking conditions. The induced cultures were further incubated at $22{ }^{\circ} \mathrm{C}$, $160 \mathrm{rpm}$ for $16 \mathrm{~h}$. A small aliquot of the cells $(100 \mu \mathrm{L})$ was checked for protein synthesis by resolving on a $12 \%$ SDS-PAGE gel. The cultures were centrifuged at $5000 \mathrm{rpm}$ for $30 \mathrm{~m}$ and the pellet was stored at $-70{ }^{\circ} \mathrm{C}$ until further use.

\subsection{Purification and Refolding of the Synthesized Proteins}

Denaturation purification of the synthesized proteins was performed using standard protocol (Qiagen, St. Louis, MO, USA) by Ni-NTA agarose column (G-Biosciences, St. Louis, MO, USA), with modifications. Briefly, the cell pellet was resuspended in $10 \mathrm{~mL}$ of native lysis buffer $\left(0.69 \% \mathrm{NaH}_{2} \mathrm{PO}_{4}, 1.75 \% \mathrm{NaCl}, 0.068 \%\right.$ imidazole, $\left.\mathrm{pH} 8.0\right)$, along with a pinch of chicken egg white lysozyme (Research Lab, Mumbai, Maharashtra, India). The resuspended cell pellet was incubated on ice for $30 \mathrm{~m}$. Pulse sonication cycles $(60 \%$ power, $5 \mathrm{~s}$ pulse, $5 \mathrm{~s}$ off; Biosafer, Zhichunli, Beijing, China) were performed for $5 \mathrm{~m}$ to completely destroy the cell pellet followed by $4{ }^{\circ} \mathrm{C}$ refrigerated centrifugation at $5000 \mathrm{rpm}$ for $40 \mathrm{~m}$. The pellet was washed three times in $10 \mathrm{~mL}$ of washing buffer ( $6 \%$ urea, $1 \%$ Triton X100, 1.3\% $\mathrm{NaH}_{2} \mathrm{PO}_{4}, 0.1 \%$ tris, $1.1 \% \mathrm{NaCl} \mathrm{pH} 8.0$ ). The solubilization of the proteins was performed by resuspending the pellet in solubilization buffer ( $48 \%$ urea, $1.3 \% \mathrm{NaH}_{2} \mathrm{PO}_{4}, 0.1 \%$ tris, $1.1 \%$ $\mathrm{NaCl}, 0.65 \%$ imidazole $\mathrm{pH} 8.0$ ) for $16 \mathrm{~h}$ at $20{ }^{\circ} \mathrm{C}$ in an orbital shaking incubator at $50 \mathrm{rpm}$. The solubilized proteins were centrifuged at $5000 \mathrm{rpm}$ for $40 \mathrm{~m}$ and the supernatant was collected. Ni-NTA agarose beads $(1.0 \mathrm{~mL})$ were added to the supernatant and incubated for $3 \mathrm{~h}$ at room temperature. This was followed by the washing of the Ni-NTA agarose, and Ni-NTA bound proteins were eluted in elution buffer ( $48 \%$ urea, $1.3 \% \mathrm{NaH}_{2} \mathrm{PO}_{4}, 0.1 \%$ tris, $1.1 \% \mathrm{NaCl}, 0.7 \%$ imidazole $\mathrm{pH} 8.0$ ). The eluted proteins were checked for purity by resolving on a $12 \%$ agarose gel. The concentration of the proteins was estimated by nanodrop (Bio-Rad, Des Plaines, IL, USA). The denatured proteins were refolded back to their native confirmation by 1-fold rapid dilution in buffer $\mathrm{A}(50 \mathrm{mM}$ tris- $\mathrm{Cl}, 9.6 \mathrm{mM} \mathrm{NaCl}$, $0.4 \mathrm{mM} \mathrm{KCl}, 1 \mathrm{mM}$ EDTA pH: 8.5). Rapid dilution of denaturated proteins has been shown to be effective for refolding of proteins, particularly membrane-associated receptors and ligands [30]. Briefly, $100 \mu \mathrm{L}$ of the eluted protein was dropped into $900 \mu \mathrm{L}$ of buffer A with constant stirring. The mixture was incubated at $4{ }^{\circ} \mathrm{C}$ for $2 \mathrm{~h}$. Activity of the protein was assessed by live-dead staining of bacteria followed by treatment with proteins, with buffer A maintained as a negative control.

\subsection{Live-Dead Staining of Bacteria and Confocal Microscopy}

The live-dead staining of bacterial cells was performed according to the protocol described by Manoharadas et al., 2021 [31]. Briefly, the staining for viable cells was performed by the addition of $5 \mu \mathrm{M}$ of SYTO9 (ThermoFischer Scientific, Bedford, MA, USA), diluted in DMSO. The staining was performed for $10 \mathrm{~m}$ in dark conditions. After incubation, the cover slips were further washed extensively with $1 \times$ PBS and final rinsing in double distilled water. In order to stain for nonviable cells, propidium iodide (ThermoFischer Scientific, Bedford, MA, USA) was diluted in $2 \times$ SSC buffer $(0.3 \mathrm{M} \mathrm{NaCl}, 0.03 \mathrm{M}$ sodium citrate, $\mathrm{pH} 7.0$ ) to a final concentration of $500 \mathrm{~nm}$. The diluted propidium iodide was added to the cells. The staining was performed for $10 \mathrm{~m}$, followed by washing with $1 \times$ PBS and final rinsing with double distilled water. The image was captured by confocal microscope (Zeiss, Jena, Germany) at an excitation/emission of 483/503 nm for SYTO9 and 535/617 nm for propidium iodide. The images were acquired on a Rolera Em-C2 camera with a $63 \times$ oil immersion objective (Zeiss, Jena, Germany). The acquired image was processed by the Zen lite software (Zeiss, Jena, Germany).

\subsection{Cell Binding Activity of Proteins and Western Blotting}

To check the binding activity of the proteins to the bacterial cells, $50 \mathrm{ng}$ of either protein CA or CA100 was added to $1 \times 10^{7}$ cells and the mixture was incubated for $10 \mathrm{~m}$ at $37^{\circ} \mathrm{C}$. The cells were pelleted by centrifugation and the cells were washed three times with 
$1 \times$ PBS. The cells were boiled and were resolved on an SDS-PAGE gel followed by Western blotting. The supernatant was precipitated by TCA and was also resolved on SDS-PAGE gel and subjected to Western blot analysis.

The Western transfer of the proteins from SDS gel onto the nitrocellulose membrane (Thermoscientific, Bedford, MA, USA) was performed by semi-dry Western blot apparatus (Bio-rad, Des Plaines, IL, USA), according to the standard protocol. The protein transferred nitrocellulose membrane was blocked in 5\% milk in $1 \times$ TBST buffer for $1 \mathrm{~h}$ at room temperature. After $1 \mathrm{~h}$, the blot was washed three times with $1 \times$ TBST buffer followed by the addition of primary antibody (mouse anti-his antibody, Abclonal, Woburn, MA, USA) diluted to a concentration of 1:2000 and incubated for $16 \mathrm{~h}$ at $16{ }^{\circ} \mathrm{C}$. The blot was further washed three times with $1 \times$ TBST and secondary antibody (goat anti-mouse IgG linked to alkaline phosphatase, Elabscience, Houston, TX, USA) was added diluted to a concentration of 1:10,000). The blot was developed, after further washing steps in $1 \times$ TBST, by the addition of BCIP/NBT (G-Biosciences, St. Louis, MO, USA).

\subsection{Software Used for Statistical Analysis of the Data}

The data obtained were analyzed for graph preparation using Microsoft Excel (2010 version). Mean values and standard deviation were calculated for each set of values using Microsoft Excel (2010 version). Error bars in the graph represent standard deviation. The statistical significance ( $p$-values) of the data values was assessed using Welch and BrownForsythe one-way Anova. The $p$-values $\geq 0.05$ were not significant (represented on the graph as ${ }^{*}$ ) and the $p$-values $\leq 0.05$ were determined as significant (represented on the graph as ${ }^{* *}$ ). The structure of both the proteins was predicted using the Phyre program [32].

\section{Results}

\subsection{Construction of $C A$ and $C A 100$}

The prediction of the structure of the catalytic domain (CHAP and amidase domain) of the endolysin from phage $\phi 11$ is shown in Figure 1A. The chimeric protein (CA100) was constructed by linking the CHAP-amidase domain of the endolysin of phage $\phi 11$ with 100 amino acid cell wall binding domain from protein P17 of the S. aureus phage $\phi 44$ AHJD (Figure 1B). As seen in Figure 1, the C-terminal cell wall binding domain (CBD) linked to the CHAP-amidase domain consists primarily of helix structure. Interestingly, the CHAPamidase protein without the CBD also had a long stretch of helix structure similar to the CBD from protein P17, invariably suggesting the capability of the CHAP-amidase domain in binding to the bacterial cells, albeit at a lower efficiency (Figure 1A). The CHAP domain is also primarily composed of a helix structure. However, the amidase domain is composed of a stranded structure. In our initial analysis, the CHAP domain alone did not show any activity. The amidase domain displayed activity against the $S$. aureus peptidoglycan. However, both the CHAP-amidase together, as found in the native endolysin, displayed a significantly higher peptidoglycan cleaving activity. Based on this initial analysis, we decided to work with the CHAP-amidase domain. The native C-terminal cell wall binding domain of the endolysin was replaced with the cell wall binding domain from protein 17 from phage $\$ 44 \mathrm{AHJD}$. It was earlier shown that the protein P17 was able to bind to a large number of $S$. aureus cells, suggesting a broader host range [33]. Hence, the linking of this cell wall binding domain to the catalytic domain presumably modifies the chimeric protein from the native phage $\phi 11$ endolysin. So, we decided to link the terminal 100 amino acid region to the CHAP-amidase domain from the endolysin of phage $\phi 11$. 
(A)
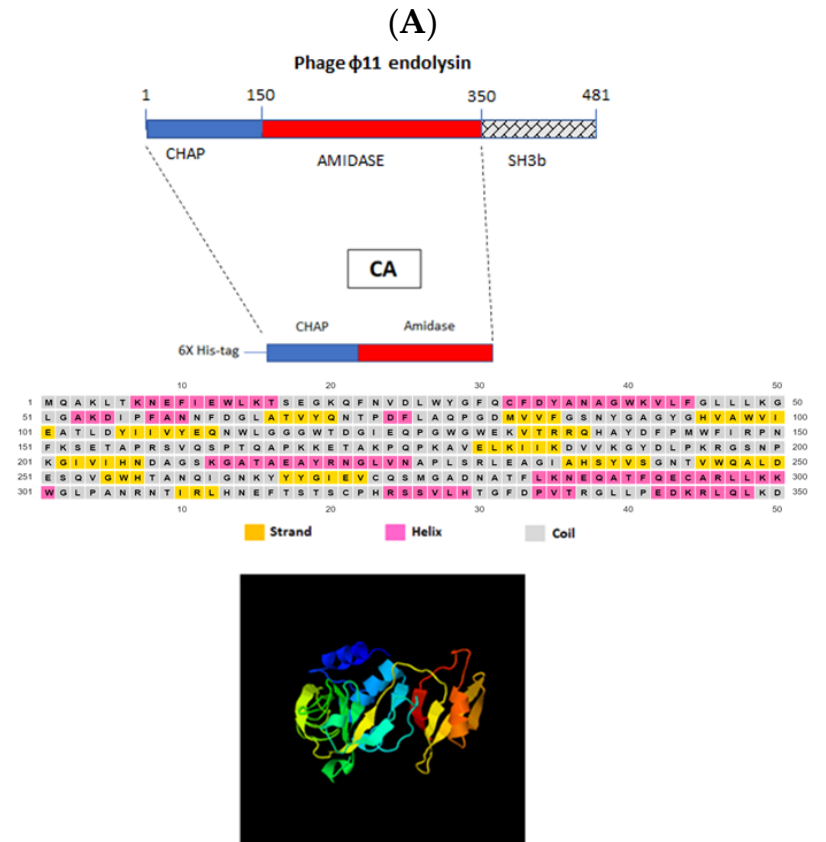

(B)

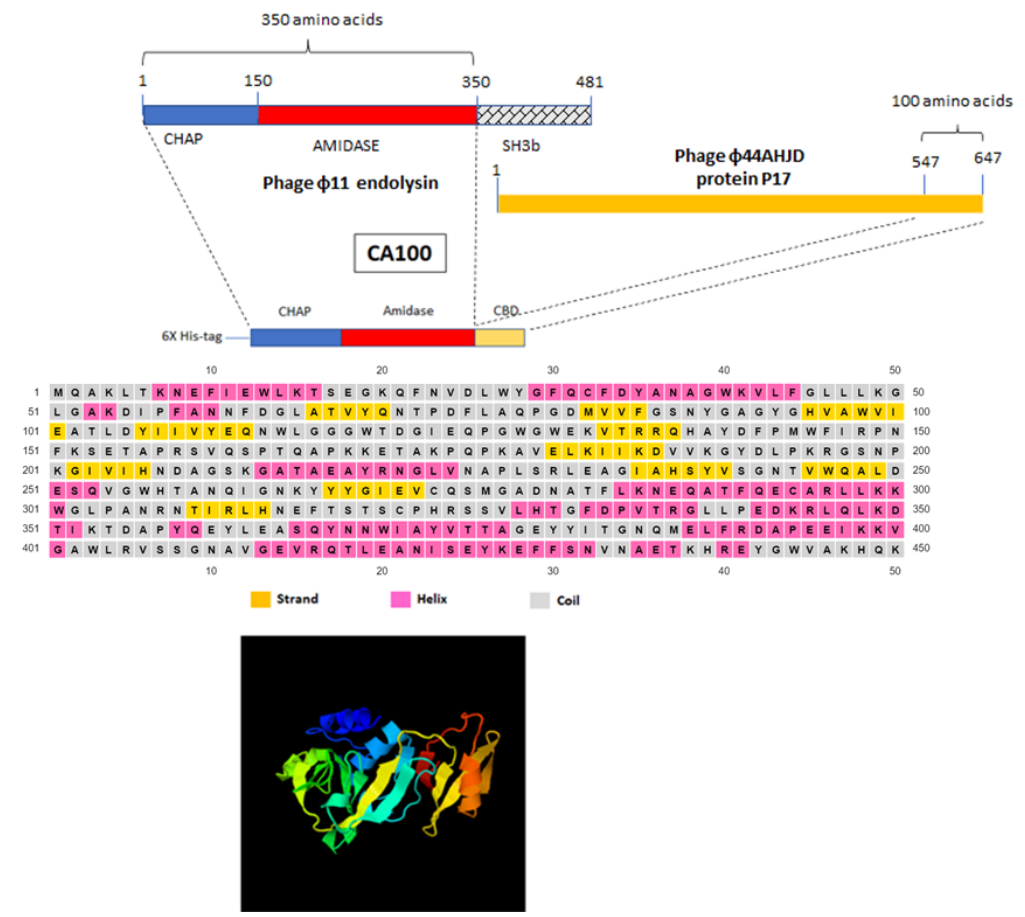

Figure 1. Modular design and structure of CA and CA100. (A) The parent protein ( $\$ 11$ endolysin) from which the domains are used for the construction of protein CA is shown. The construction of protein $\mathrm{CA}$, encompassing the $\mathrm{CHAP}$ and amidase domain with purification to be enabled by $\mathrm{N}$ terminal 6x-histidine tag residues. The catalytic motifs CHAP and amidase are primarily composed of a coil structure (grey) with a few stretches of helix structure (pink). The C-terminal portion of protein CA also had a few helical stretches. The residues in yellow represent stranded structure. The predicted tertiary structure is also shown. (B) Protein CA100 had a 100 amino acid truncated cell wall binding domain (CBD) domain from protein 17 of phage $\$ 44 \mathrm{AHJD}$. The CBD predominantly comprised of a helix structure with a few stretches of coil structure. Stranded structure (yellow) was completely absent in the CBD. The predicted tertiary structure of CA100 is shown at the bottom. 


\subsection{Purification and Activity Checking of $C A$ and $C A 100$}

Both gene CA and CA100 were cloned into pQE30 expression vector as BamHI/HindIII. The expression was performed by induction with $0.5 \mathrm{mM}$ IPTG at an $\mathrm{OD}_{600}$ of 0.5. The expressed protein had N-terminal 6x histidine tag for purification with Ni-NTA column. The peptidoglycan cleaving activity of the expressed proteins were assessed on a zymogram with embedded clinical MRSA peptidoglycan. As seen in Figure 2A, the peptidoglycan cleaving activity of crude proteins CA and CA100 was detected on zymogram (lane 3 and 4 ), respectively. The expressed proteins were purified over the Ni-NTA column; the purity of the proteins was tested by loading onto SDS-acrylamide gel. As seen in Figure 2B, the proteins were $\approx 95 \%$ pure as visually analyzed from the gel. The proteins were purified after denaturation in $8 \%$ urea. Refolding of the proteins was performed by rapid dilution (1-fold) in buffer A. The refolded proteins were checked for stability in SDS- acrylamide gel. The refolded proteins were stable and no major degradation products were observed (Figure 2C). The concentration of the refolded proteins was estimated to be $0.4 \mathrm{mg} / \mathrm{mL}$ by nanodrop (Thermoscientific, Bedford, MA, USA).

(A)

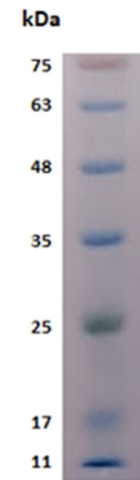

(B)

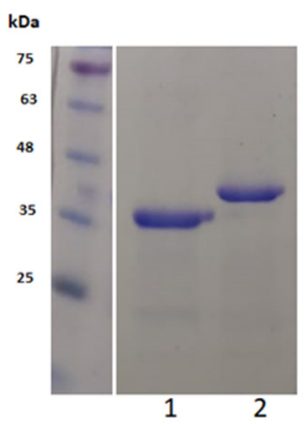

(C)

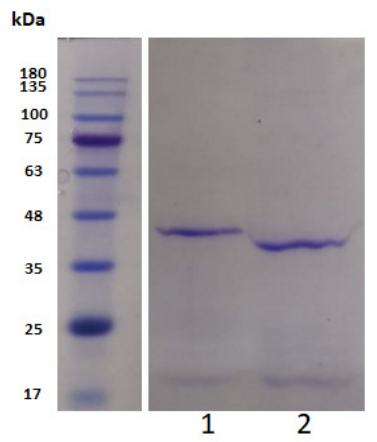

Figure 2. Expression and purification of CA and CA100. (A) The synthesized proteins CA and CA100 after IPTG induction of the genes are shown in lanes 1 and 2 . The peptidoglycan cleaving activity of the proteins was checked on a zymogram with gel-embedded MRSA peptidoglycan shown on lanes 3 and 4 . (B) The synthesized proteins were purified by Ni-NTA agarose. The proteins were $\approx 95 \%$ pure as judged on a SDS-PAGE gel. The purified proteins CA and CA100 are shown in lanes 1 and 2, respectively. (C) The denaturated proteins CA and CA100 were refolded back by rapid dilution in buffer A. The refolded proteins CA100 and CA used for further studies are shown in lanes 1 and 2, respectively.

\subsection{CA100 Displays Activity against MRSA and S. aureus 8325-4}

To test the activity of the refolded proteins against $S$. aureus strains, $1 \times 10^{7}$ cells were resuspended in buffer $\mathrm{A}(\mathrm{pH}$ 8.5). Ten micrograms of the purified and refolded proteins, CA and CA100 were added to the resuspended cells. The mixture was incubated at $37^{\circ} \mathrm{C}$ for 
$1 \mathrm{~h}$. The live and dead cells following the treatment were assessed by confocal microscopy. The protein CA100 displayed activity against S. aureus 8325-4 (Figure 3A) and clinical MRSA cells (Figure 3B). In the case of $S$. aureus 8325-4, the number of CA-treated dead cells was $25 \%$ within $10 \mathrm{~m}$. The number further dropped to $35 \%$ within $30 \mathrm{~m}$ of treatment and the number stayed almost the same until $60 \mathrm{~m}$ of treatment (Figure 3A). However, in the case of $S$. aureus 8325-4 cells treated with CA100, the number of dead cells was 35\% within $10 \mathrm{~m}$ of treatment. The number of dead cells increased to $45 \%$ within $30 \mathrm{~m}$ and at the end of $60 \mathrm{~m}, 52 \%$ of $S$. aureus $8325-4$ cells was observed to be dead (Figure 3A).

The treatment of the clinical MRSA strain with proteins CA and CA100 was interesting as protein CA did not show any activity against the MRSA strains until $60 \mathrm{~m}$ of treatment. However, the number of MRSA cells treated with CA100 displayed activity as $18 \%$ of dead cells were observed at $10 \mathrm{~m}$ of treatment. These values further reduced to $42 \%$ and $47 \%$ within $30 \mathrm{~m}$ and $60 \mathrm{~m}$ of treatment (Figure 3B). We further tested these proteins (CA and CA100) against a clinical E. coli isolate (KKH001) (Figure 3C) and veterinary isolate of S. aureus (Rumba) (Figure 3D). The E. coli KKH001 was maintained as a negative control as the outer LPS membrane was expected to prevent the access of the exolysins to the peptidoglycan. As seen in Figure 3C, neither of the two proteins was active against E. coli KKH001 until $60 \mathrm{~m}$ of treatment. Interestingly, the veterinary isolate, S. aureus Rumba was also not affected by both the proteins (Figure 3D), presumably suggesting that varied peptidoglycan chemistry exists in S. aureus Rumba.

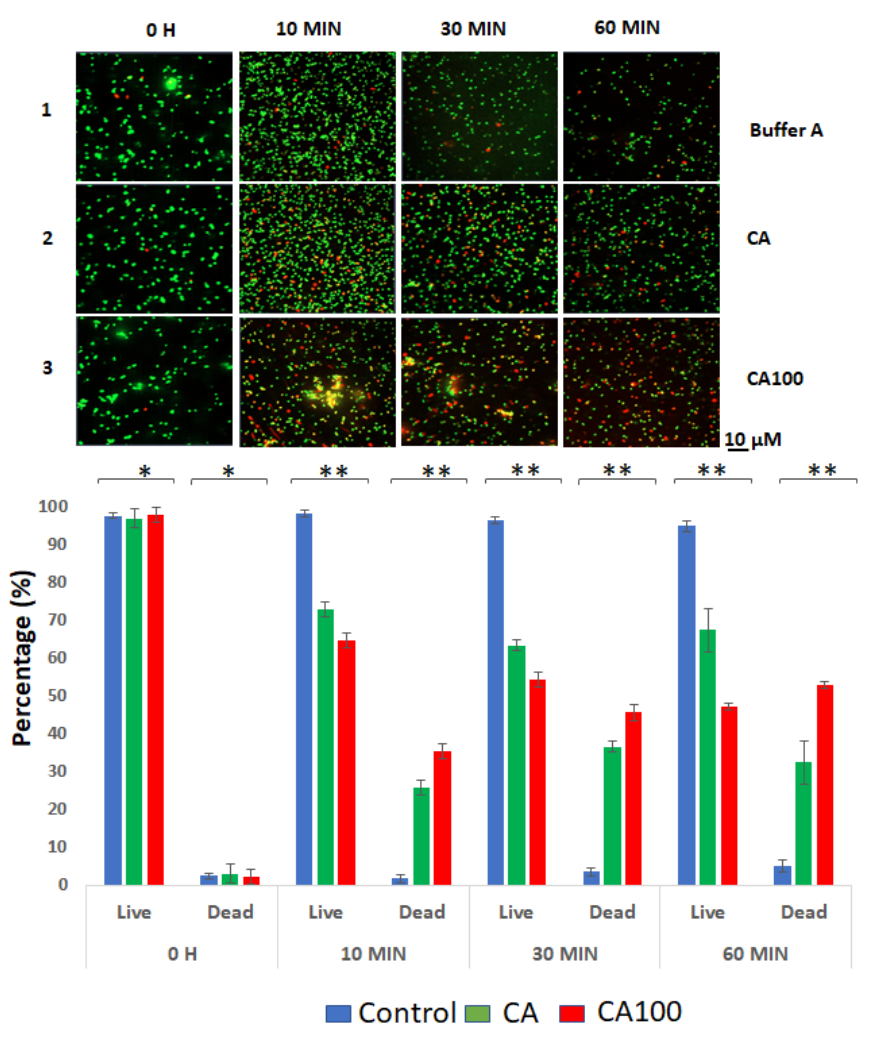

(A)

Figure 3. Cont. 

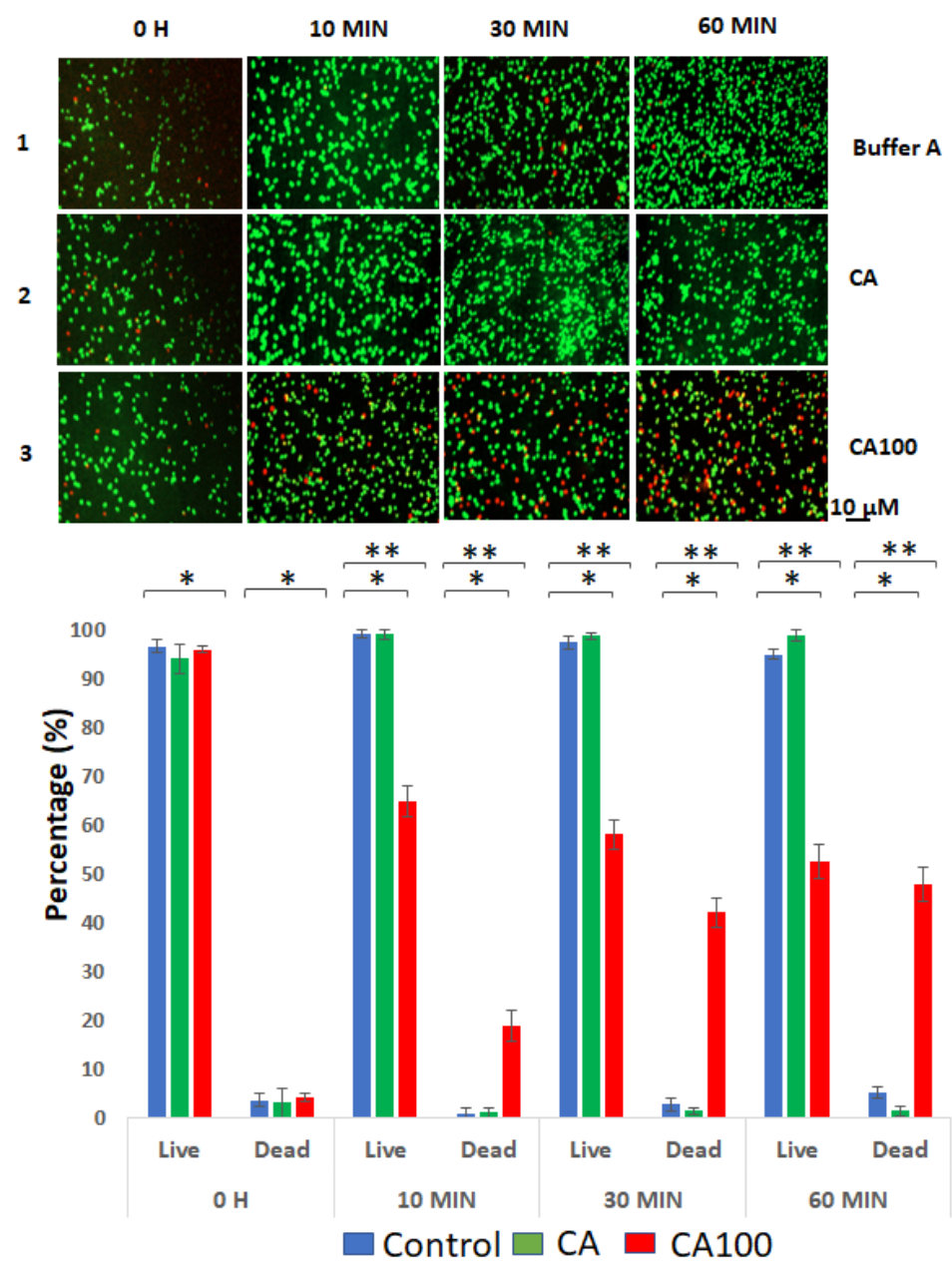

(B)

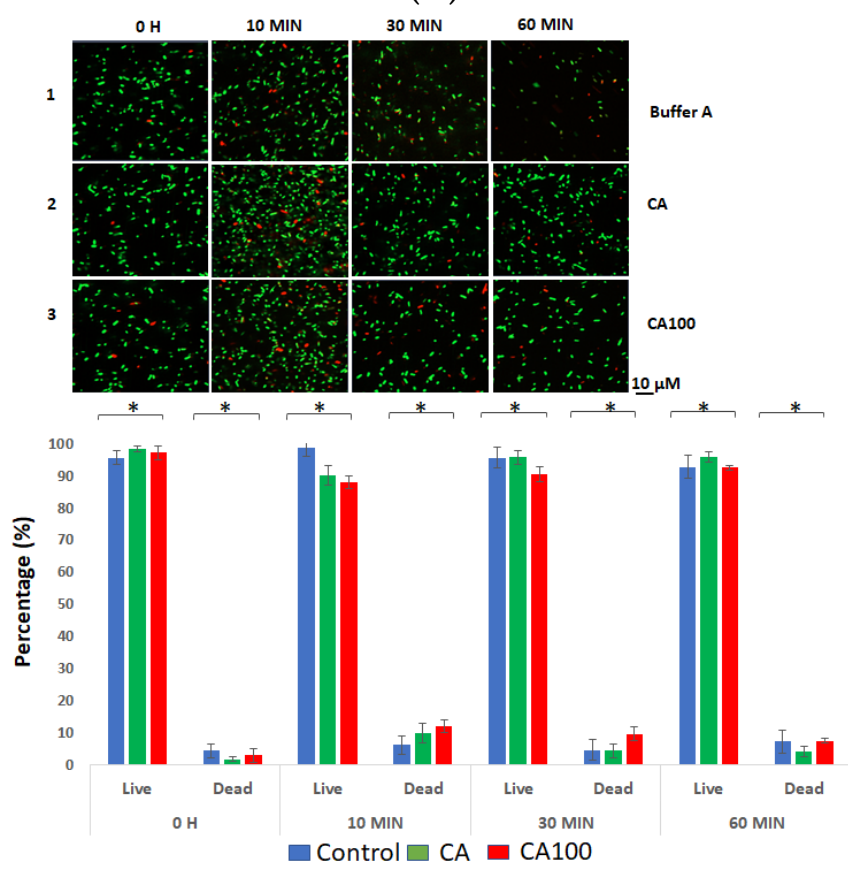

(C)

Figure 3. Cont. 


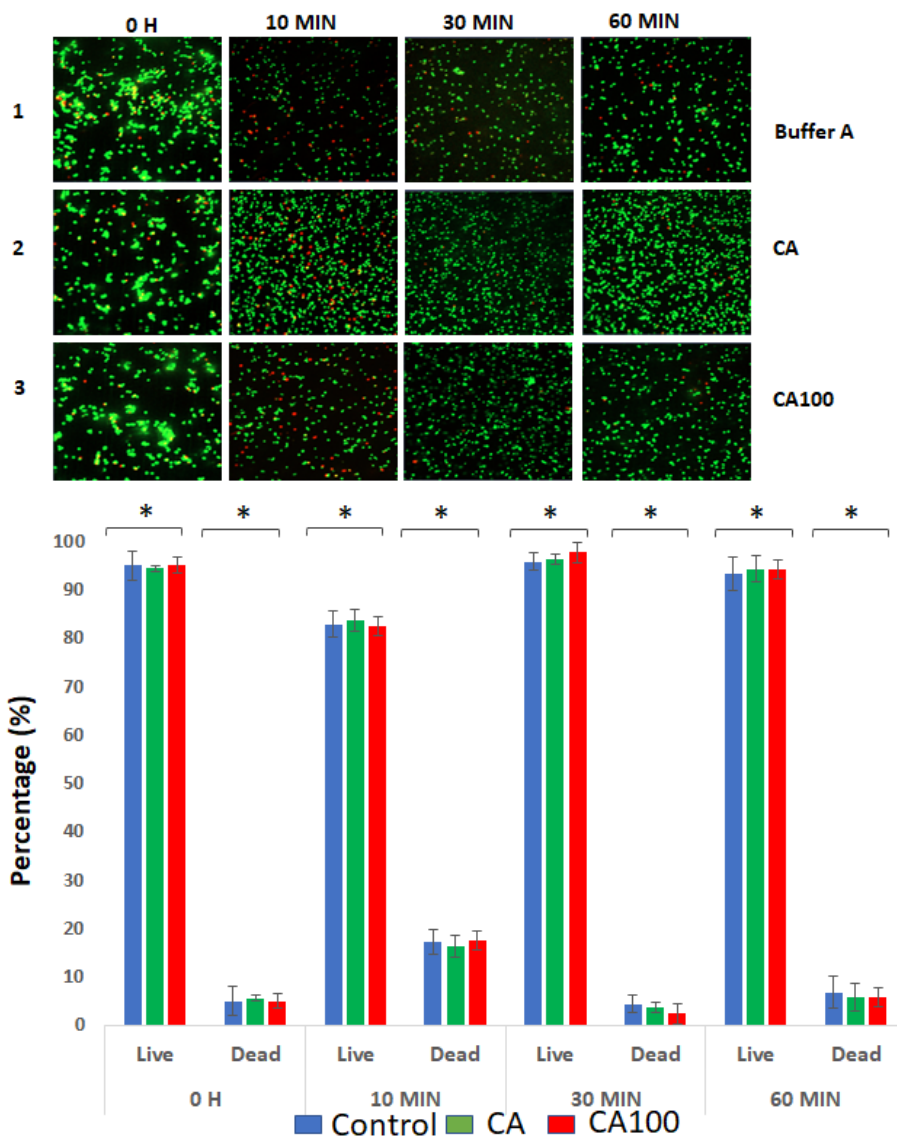

(D)

Figure 3. Live-dead staining of bacterial cells treated with proteins CA and CA100 (A) The treatment of $S$. aureus $8325-4$ cells with protein CA caused a reduction of live cells by $23 \%, 63 \%$ and $67 \%$ within $10 \mathrm{~m}, 30 \mathrm{~m}$ and $60 \mathrm{~m}$ (lane 2). The reduction of live cells with CA100 amounted to $35 \%, 45 \%$ and $52 \%$ within $10 \mathrm{~m}, 30 \mathrm{~m}$ and $60 \mathrm{~m}$ (lane 3). The live cell in the buffer control was fixed to $100 \%$ at $0 \mathrm{~h}$ (lane 1). (B) The treatment of clinical MRSA cells with protein CA did not cause any reduction of live cells until $60 \mathrm{~m}$ in comparison with the buffer control (lane $2 \mathrm{vs}$. lane 1). The treatment of MRSA cells with CA100 caused a reduction in live cells amounting to $18 \%, 42 \%$ and $47 \%$ within $10 \mathrm{~m}, 30 \mathrm{~m}$ and $60 \mathrm{~m}$ (lane 3). (C) No reduction in live cells of clinical E. coli KKH001, in comparison to the control was seen within the tested time frame (lane 1 vs lane 2 vs. lane 3). (D) Treatment of S. aureus Rumba with CA and CA100 did not cause any visible reduction of live cells in comparison with the buffer control within the treated time (lane 1 vs. lane 2 vs. lane 3). The experiment was performed in triplicate and the error bars representing standard deviation are shown. Statistical significance level was calculated using one-way ANOVA (Welch and Brown-Forsythe) ${ }^{*} p \geq 0.05 ;{ }^{* *} p \leq 0.05$ ).

\subsection{Spectrophotometric Analysis of the Protein Treated Cells}

In our previous experiment described in Section 3.3, we used the live-dead assay to determine the percentage of live and dead cells, which was observed by confocal microscopy. However, it was shown earlier that a localized rupture of the peptidoglycan leads to the loss of turgor pressure within the bacterial cell, leading to lysis and immediate death of the bacterium [5]. In the case of the lysis of bacterium, the genetic material would be leaked out, leaving only the debris. This would leave the propidium iodide unable to bind to the cellular DNA in live-dead staining. In order to have a direct inference about the activity of the proteins CA and CA100 on target bacteria, we measured the $\mathrm{OD}_{600}$ of the bacterial cells at different time points after treatment with the proteins. Similar to what was observed with the live-dead staining, the $\mathrm{OD}_{600}$ of $S$. aureus $8325-4$ cells dropped by $28 \%$ within $10 \mathrm{~m}$ after treatment with protein CA. No major decrease in the OD $_{600}$ was 
observed at further time points with the final value reaching $33 \%$ at the end of $60 \mathrm{~m}$ after treatment (Figure $4 \mathrm{~A}$; orange bars). In case of the treatment with $\mathrm{CA} 100$, the $\mathrm{OD}_{600}$ of S. aureus 8325-4 significantly reduced over time. A major drop of $54 \%$ was observed after $10 \mathrm{~m}$ following treatment of cells with the CA100 protein. The $\mathrm{OD}_{600}$ further reduced by $93 \%$ and $96 \%$ at the end of $50 \mathrm{~m}$ and $60 \mathrm{~m}$, respectively (Figure $4 \mathrm{~A}$; green bars). This clearly states the antimicrobial activity of CA100 against $S$. aureus 8325-4.

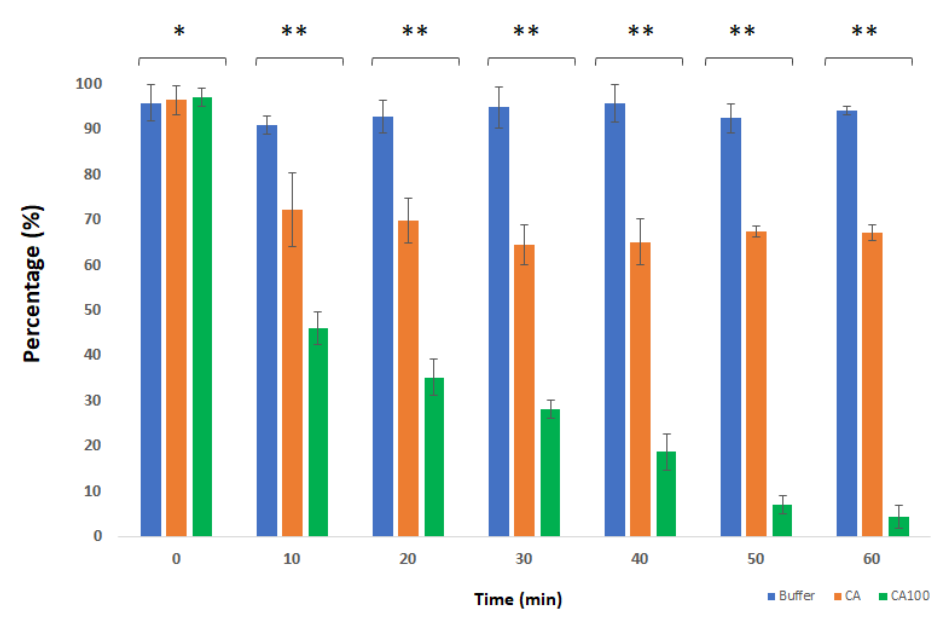

(A)

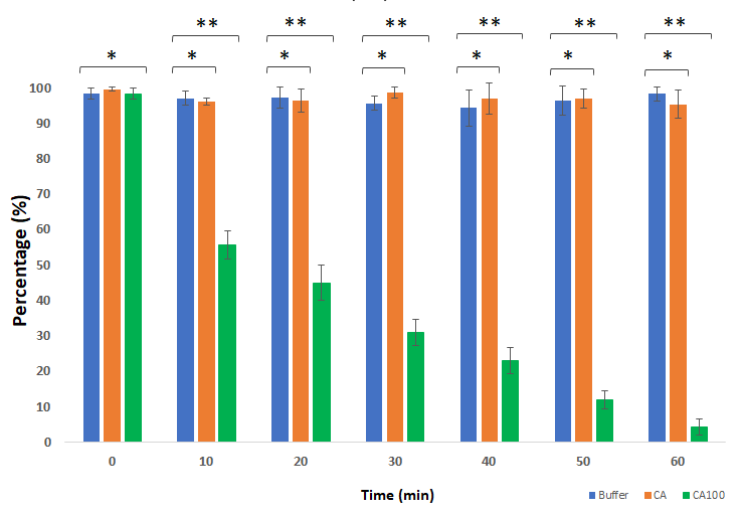

(B)

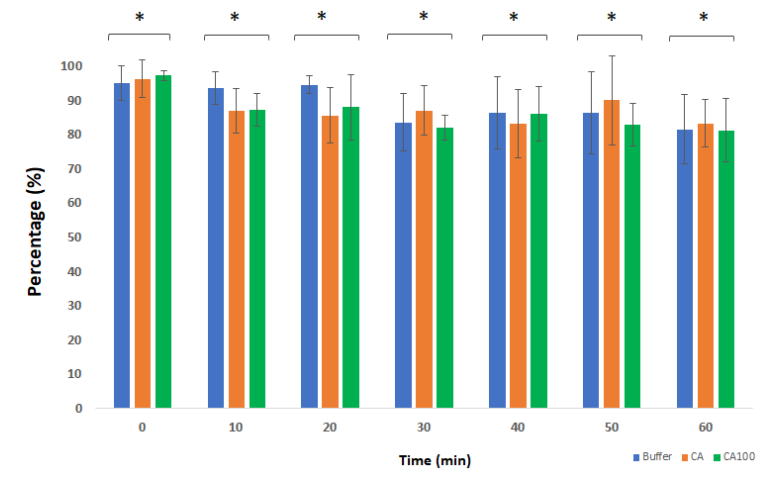

(C)

Figure 4. Cont. 


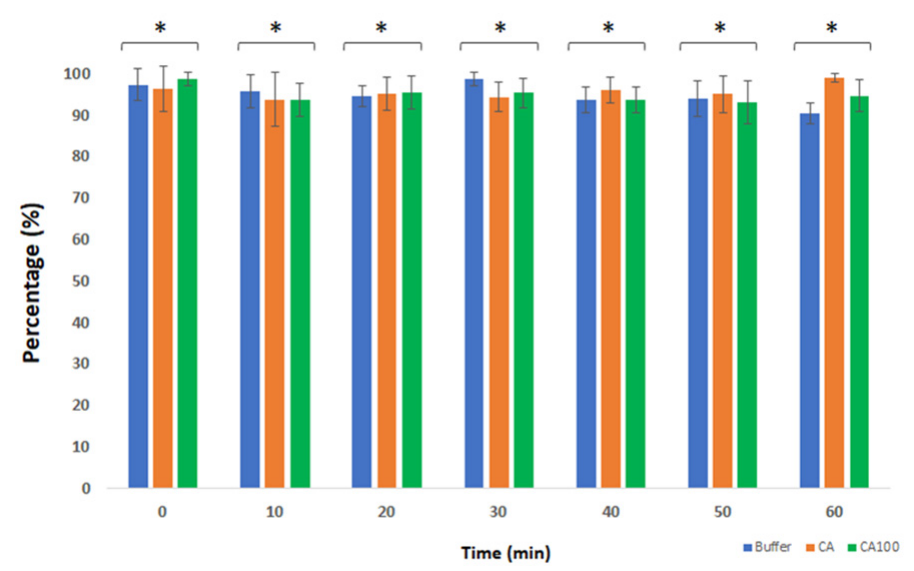

(D)

Figure 4. Spectrophotometric measurement analysis of the treated cells. (A) The reduction of cell density of $S$. aureus $8325-4$ was measured spectrophotometrically at $\mathrm{OD}_{600}$. A decline in the cell density was seen in the CA treated sample amounting to $28 \%$ within $10 \mathrm{~m}$ and the percentage of reduction saturating at around $35 \%$ until $60 \mathrm{~m}$ of treatment. The reduction in live cell density was sharper in samples treated with CA100 with 54\% reduction in $10 \mathrm{~m}$ (orange bar). The reduction was more prominent in the further tested time frame with the intensity dropping by more than $95 \%$ at the end of $60 \mathrm{~m}$ (green bar). Buffer control was set at $100 \%$ at $0 \mathrm{~h}$ for comparison (blue bar). (B) The treatment of MRSA strain with CA did not show any marked reduction in cell density in comparison with the control (orange bar vs. blue bar). The CA100 was effective in reducing the cell density with values dropping by $45 \%$ within $10 \mathrm{~m}$ of treatment. The cell density further reduced at the following time points with more than $95 \%$ reduction within $60 \mathrm{~m}$ of treatment (green bar). (C) No reduction in cell density was observed with either of the protein-treated E. coli KKH001 samples until $60 \mathrm{~m}$ (blue bar vs. orange bar vs. green bar). (D) Similar to E. coli KKH001, CA- and CA100-treated $S$. aureus Rumba cells did not show any reduction in cell density until $60 \mathrm{~m}$ following treatment (blue bar vs. orange bar vs. green bar). The experiment was performed in triplicate and the error bars represent standard deviation. The statistical significance level was calculated using one-way ANOVA (Brown-Forsythe and Welch) $\left({ }^{*} p \geq 0.05 ;{ }^{* *} p \leq 0.05\right)$.

The treatment of MRSA cells with proteins CA and CA100 drew a different picture in comparison with $S$. aureus $8325-4$. No activity was seen with protein CA against MRSA (Figure 4B; orange bars). However, CA100 displayed activity against MRSA with the $\mathrm{OD}_{600}$ dropping by $55 \%$ within $10 \mathrm{~m}$ of treatment (Figure $4 \mathrm{~B}$; green bars). The drop in $\mathrm{OD}_{600}$ was consistent over time with only $4 \%$ of intact cells remaining after $60 \mathrm{~m}$ of treatment (Figure 4B; green bars).

In the live/dead experiment, no activity was seen for both the proteins CA and CA100 against $S$. aureus Rumba and E. coli KKH001. We wanted to test the effect that CA and CA100 had against both these strains spectrophotometrically. As seen in Figure 4C,D, no decrease in $\mathrm{OD}_{600}$ was noticed following treatment of E. coli KKH001 and S. aureus Rumba, respectively, with proteins CA and CA100.

\subsection{Cell Wall Binding of the Proteins Determine Activity}

We wanted to further test the cell wall binding of the proteins CA and CA100 to bacterial cells. We were particularly interested to see the binding of the proteins to $S$. aureus Rumba, as we did not observe any activity upon treatment with the proteins. Protein CA was found to be partially active against $S$. aureus $8325-4$. We next tested the binding of the CA and CA100 proteins towards S. aureus 8325-4. A faint band of the cell pellet bound protein CA was seen after Western blotting. No protein was found in the supernatant fraction (Figure 5A; lane 1, 2). In contrast with CA, a strong pellet binding was observed with protein CA100. No complete $(100 \%)$ binding was also observed with CA100 to the 
cell pellet, as a minor fraction of protein CA100 was also seen in the supernatant (Figure 5B; lane 3,4). However, this pellet binding of CA100 was sufficient to exert a strong antibacterial activity.

(A)

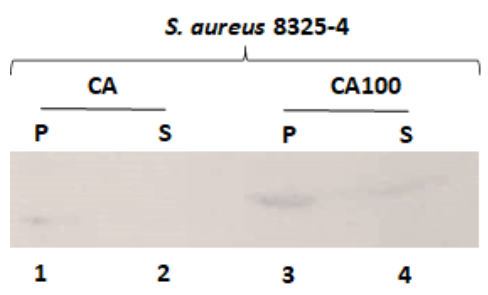

(C)

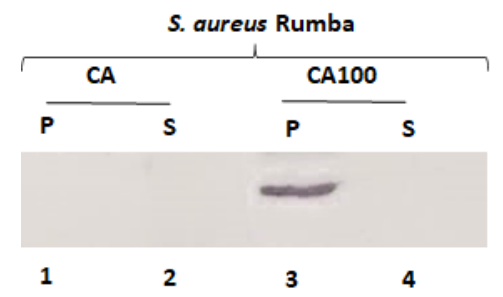

(B)

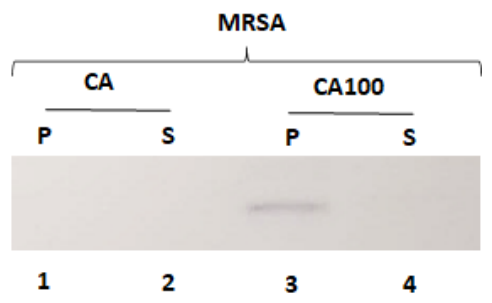

(D)

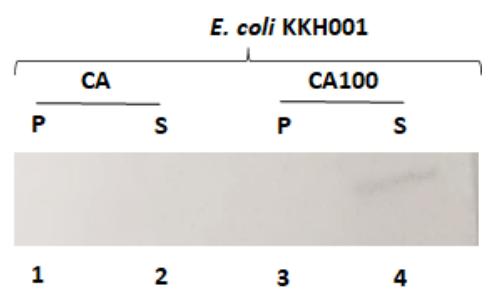

Figure 5. Assessment of cell wall binding ability of proteins CA and CA100. (A) The binding assay with S. aureus 8325-4 was performed with proteins CA and CA100. A weak binding of the protein CA was seen (lane 1). No protein was seen in the supernatant fraction (lane 2). A predominant amount of protein CA100 was bound to the cells (lane 3) and only a very small percentage was seen in the supernatant fraction (lane 4). (B) The protein CA100 was able to bind strongly to MRSA cells with almost complete protein CA100 bound to the cell pellet (lane 3). No protein was seen on the unbound supernatant fraction (lane 4). No cell wall binding was seen with protein CA (lane 2), neither was the protein found in the unbound supernatant fraction (lane 1). (C) A strong binding of CA100 was seen towards S. aureus Rumba with almost complete amount of the protein bound to the cell pellet (lane 3) and no protein was seen in the supernatant fraction (lane 4). Protein CA was neither found to be bound to the cell pellet (lane 1) nor found in the supernatant fraction (lane 2). (D) Neither protein, CA nor CA100, was able to bind to E. coli KKH001 (lane 1 and lane 3). The unbound CA100 protein was detected in the unbound supernatant fraction (lane 4). Protein CA was not detected in the supernatant fraction as well (lane 2).

The protein CA did not bind to the MRSA strain. No CA protein was found in either the pellet or supernatant fraction (Figure $5 B$; lane 1, 2). In contrast, CA100 protein bound strongly to the MRSA and the pellet bound protein was detected by Western blot (Figure 5B; lane 3,4$)$. This finding could answer why no activity was seen when CA protein was added to MRSA cells. The absence of CA protein in the supernatant also suggests that the protein may be degraded.

We did not observe any activity against $S$. aureus Rumba with either CA or CA100. We hypothesized that this could be because of the inability of the proteins to bind to the bacteria. To check this, CA or CA100 was tested for binding to S. aureus Rumba. Protein CA was found not to bind to the bacteria. No CA protein was found either in a pellet or supernatant fraction (Figure 5C; lane 1, 2). In contrast to our initial hypothesis, the CA100 protein was found to strongly bind to $S$. aureus Rumba (Figure 5C; lane 3). This result was interesting, as the protein CA100 could not exert antibacterial activity, in spite of its strong interaction with S. aureus Rumba. No CA100 protein was found in the unbound supernatant fraction (Figure 5C; lane 3), suggesting that most of the protein was bound to the cell pellet.

We also tested the binding of the proteins to the Gram-negative E. coli KKH001. As expected, neither CA nor CA100 was able to bind to the bacteria (Figure 5D; lane 1,3). Protein CA was also not present in the unbound supernatant fraction (Figure 5D; lane 2). 
Protein CA100 was found in the supernatant fraction, confirming the inability of CA100 to bind to E. coli KKH001 (Figure 5D; lane 4).

\subsection{Spot Analysis Shows the Activity of CA and CA100}

Earlier experiments showed that CA100 was efficient against S. aureus 8325-4 and the clinical MRSA strain in liquid media. The CA protein however displayed nominal activity against $S$. aureus $8325-4$ and showed no major activity against MRSA. In order to check the activity of protein CA and CA100 on solid media-grown bacteria, we did a spot analysis of both the proteins on S. aureus 8325-4 and MRSA. This work was performed particularly to assess the ability of the proteins in countering immovable bacteria especially in biofilm settings. Five $\mu \mathrm{L}$ of both the proteins $(2 \mu \mathrm{g} / \mu \mathrm{L})$ was spotted on a lawn of either S. aureus 8325-4 or MRSA. Both CA and CA100 were able to display activity against both the bacteria (Figure 6). It was interesting that CA was also active against MRSA in solid agar plates. The inability of CA to bind to MRSA was the factor that inhibited its activity in liquid suspension. As expected, CA100 shows activity against both the tested strains. Since no activity was observed with CA100 against $S$. aureus Rumba in spite of its strong binding, it was not tested on solid media. Gram-negative E. coli KKH001 have an outer LPS membrane that refrain the access of the exolysins to the peptidoglycan, hence was not tested on the solid media.

\section{S. aureus $8325-4$}

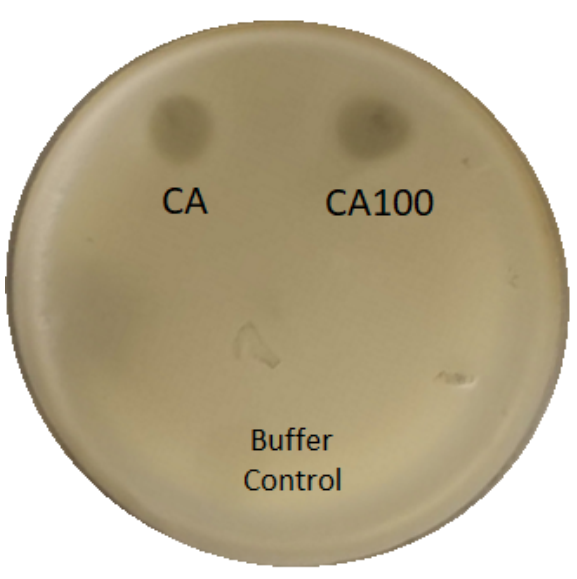

\section{Clinical MRSA}

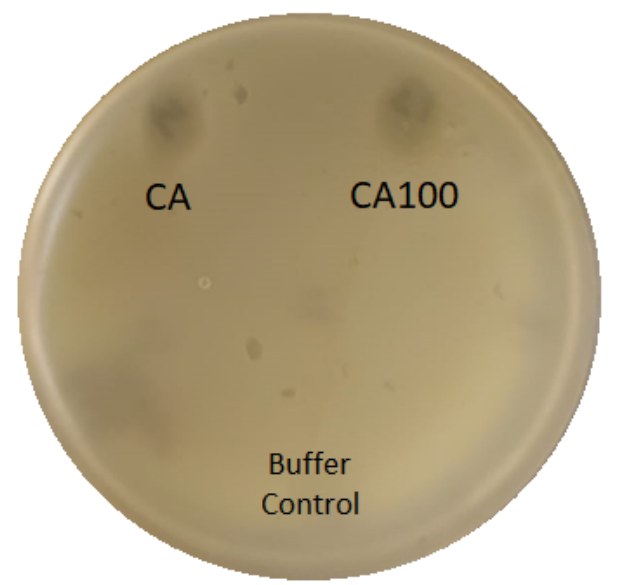

Figure 6. Spot analysis to determine activity of proteins against immovable cells. Proteins CA and CA100 $(5 \mu \mathrm{L})$ were spotted on a lawn of $S$. aureus $8325-4$ and MRSA. Buffer A was also spotted as a negative control. The plates were incubated at $37^{\circ} \mathrm{C}$ for $16 \mathrm{~h}$. Both CA and CA100 displayed antimicrobial activity against both the tested strains. The activity can be seen as a spot where no growth of bacteria was seen. No activity was seen in the region where buffer control was spotted.

\section{Discussion}

There is an emergence of antibiotic-resistant bacteria with the list increasing rapidly over last few years and lesser new antibiotics are in the pipeline. This scenario has led to an intense need for novel types of antibiotics, to prevent public health crises [34]. Canonical antibiotics usually target critical bacterial processes like nucleic acid and protein synthesis, metabolic pathways or building of the outer cell envelope. Bacteria however overcome these challenges by either mutating the antibiotic target, inactivating the antibiotics or pumping them out using efflux pumps [35].

Bacteriophage-encoded lysins began to be used as a rapid and specific treatment to kill pathogenic bacteria 20 years ago [7]. The usage of purified phage lysins exogenously against pathogenic bacteria was called 'enzybiotics'. One among the marked advantages of enzybiotics is that they target specific bonds in the bacterial peptidoglycan. Mutations in bacterial peptidoglycan often lead to compromising fitness in bacteria, hence, the emer- 
gence of bacterial resistance is highly unlikely [36,37]. Enzybiotics have been shown to be mostly active against Gram-positive bacteria and relatively unaffected Gram-negative bacteria, owing to the presence of an outer lipopolysaccharide membrane, which would act as a permeability barrier rendering inaccessibility to the lysin from reaching the bacterial peptidoglycan. In recent years, enzybiotics has been proposed as an important antimicrobial regime for containing multidrug-resistant Gram-positive bacteria [38-41]. Staphylococcus aureus has been a major nosocomial pathogen, associated with various infections like pneumonia, osteomyelitis and meningitis [42,43]. Furthermore, the development of antibiotic resistance by $S$. aureus has posed additional threats in hospitals [44].

We have devoted this study to the development of a chimeric enzybiotic against $S$. aureus strains. The strategy was to combine the catalytic domain of the endolysin from phage $\phi 11$ with the cell wall binding domain from protein 17 of phage $\phi 44 \mathrm{AHJD}$. The native catalytic domain comprises of the CHAP domain and the amidase domain. Both the domains were kept intact as removal of either of the domains compromised the activity of the protein. The native cell wall binding domain was replaced with the truncated cell wall binding domain from protein 17 of phage $\$ 44$ AHJD, comprising of 100 amino acids. Earlier studies have pointed out that protein 17 from phage 444 AHJD was able to efficiently bind to a large number of $S$. aureus strains [33]. Protein 17 is a minor structural protein of phage $\$ 44 \mathrm{AHJD}$ [45]. Moreover, the cell wall binding domain in protein 17 was proposed harbored within the C-terminal 25 amino acid region [6]. In our study, we basically compared the activity of two recombinantly synthesized proteins: CA and CA100. Protein CA comprised only of the catalytic domains, CHAP and amidase in tandem. CA100 however had an additional truncated cell wall binding domain downstream of the catalytic domains.

As is similar with the recombinant expression of other endolysins, proteins CA and CA100 were also expressed in inclusion bodies. Denaturation purification by solubilization of inclusion bodies by urea, followed by refolding of the proteins by rapid dilution to native confirmation was employed to purify the proteins. However, one disadvantage associated with rapid dilution was that the final concentration of proteins was reduced by 10 times. To counter this, we concentrated the Ni-NTA eluted proteins by Spin X concentrating columns (Corning, Corning, NY, USA), before rapid dialysis. The diluted and refolded proteins were further concentrated by Spin $X$ columns. The activity of the refolded proteins was assessed by live-dead staining of bacterial cells after treatment with proteins.

Both the proteins CA and CA100 were found to be active against S. aureus 8325-4, however at variance. Protein CA was only partially active against S. aureus $8325-4$, with $32 \%$ reduction of live cells within $60 \mathrm{~m}$ of treatment. However, protein CA100 was significantly more active against $S$. aureus 8325-4, with 52\% reduction in live cells within $60 \mathrm{~m}$ of treatment. In the case of the clinical MRSA strain, only CA100 was found to be active with $47 \%$ reduction in live cells. Both the proteins were not active against the veterinary isolate S. aureus Rumba and clinical E. coli strain KKH001. These data were based on the staining of cells with SYTO9 dye and propidium iodide, to differentiate live and dead cells. In the case of Gram-positive bacteria, the peptidoglycan functions as the major structural component of the cell, supporting an internal turgor pressure of 20-50 atmospheres [30,46-48]. Any breach or rupture of the peptidoglycan layer results in osmotic lysis and cell death of the bacterium, similar to the phage progeny release during the culmination of the lytic infective cycle [8]. This bacterial rupture possibly leaks out the nucleic acids, hence livedead staining does not provide a direct inference of the dead cells after treatment with the proteins. In order to have a direct assessment of the activity of the proteins on bacterial cells, spectrophotometric reduction assay of the cells was performed after treatment. The CA100 protein caused a 96\% reduction in clinical MRSA cells within $60 \mathrm{~m}$ of treatment. As observed earlier, the CA protein was found not to be active against MRSA. The treatment of S. aureus 8325 with the CA and CA100 proteins showed a decline of live cells by $33 \%$ and $96 \%$, respectively, within $60 \mathrm{~m}$ of treatment. Similar to the observation with live-dead staining, none of the proteins were active against $S$. aureus Rumba and E. coli KKH001. We 
hypothesized that the inactivity of the proteins against $S$. aureus Rumba could be because of the inability of the proteins to bind to the bacteria. To confirm this, we did a binding assay of the proteins towards the bacterial strains. Interestingly, CA100 was able to bind strongly to $S$. aureus Rumba. In addition, CA100 was also able to bind to MRSA and S. aureus 8325-4. As expected, CA100 did not bind to E. coli KKH001. Another important observation was that the CA protein was only able to partially bind to S. aureus 8325-4 and not to any other tested strains. However, CA was also not detected in the supernatant fraction stating that the cell wall binding domain in CA100 also presumably stabilizes the protein in addition to its cell wall binding function. Since we observed a weak binding of the CA protein to S. aureus 8325-4, we hypothesized that CA could exert its activity to the full potential in immovable cells. Spotting assay of proteins CA and CA100 was performed on a lawn of $S$. aureus Rumba and S. aureus 8325-4. Spot analysis was particularly carried out to know if the CA protein could exert activity against immovable S. aureus 8325-4 and MRSA, as cell wall binding domain is mostly necessary to bind the protein tightly to the bacterial cell in a liquid or moving culture. As hypothesized, both the proteins showed antibacterial activity on a spot test, further stating that the cell wall binding domain is indispensable for potent activity and stability of the constructed proteins.

Domain replacement strategy has been a forerunner in the creation of chimeric and novel enzybiotics in the recent decade. Apart from domain replacement, truncation and other modifications have been successfully tested to create more potential proteins against Gram-positive pathogens. In a recent study, a recombinant version of lysostaphin, LYSSTAPH-S and LYSDERM-S was created by gene sequence optimization and truncation of the pre-domain, to create a more effective protein that could be expressed and purified from E. coli [11]. In an earlier study, lysibodies were created by fusing cell wall binding domains from phage endolysins to IgG Fc, thereby creating novel therapeutic antibodies. This study also depicts the importance and specificity of the cell wall binding domain of phage lysins [49]. Engineering of phage endolysins also shows several advantages in comparison with their parental counterparts. In the activity level, the engineered phage lysins display an enhanced killing of bacteria in various growth conditions, thereby increasing the natural bactericidal spectrum [27]. The engineered lysins may also display increased solubility and subsequent stability at the production level. The increase in the catalytic activity of a modified phage endolysin was shown in a study, where a domain swapping or combinational approach was performed between the catalytic and cell wall binding domain from two Listeria monocytogenes phage endolysins, Ply118 and PlyPSA. A threefold higher activity against Listeria serovars was displayed by one of the engineered endolysins, EAD118_III_CBDPSA, in comparison with the parental lysin, PlyPSA [50]. The solubility of the phage lysins was improved by engineering of the endolysins to include a more soluble cell wall binding domain instead of the native cell wall binding domain. For instance, the chimeric endolysin, ClyS was composed of the catalytic domain from the endolysin (PlyTW) of S. aureus phage Twort and the cell wall binding domain from the endolysin of S. aureus phage phiNM3. The engineered endolysin ClyS displayed high solubility in production analysis. In addition, ClyS displayed a broad spectrum of activity against several Staphylococcus species both in vitro and in vivo [51,52].

We too have aimed to create a chimeric endolysin (CA100) with enhanced specificity and solubility. In our initial studies, the native endolysin of phage $\phi 11$, encompassing the catalytic and cell wall binding domain could not be purified to homogeneity owing to solubility problem (data not shown). The engineered protein, CA100, however was better soluble and displayed activity against the clinical MRSA strain.

\section{Conclusions}

Enzybiotics is an ever-emerging field to counter multidrug-resistant bacterial pathogens. With a rapid emergence of antibiotic-resistant strains and lack of new antibiotics, enzybiotics could play a pivotal role in antimicrobial therapy in the near future. Herein, we replaced the cell wall binding domain of the endolysin from phage $\phi 11$ with a truncated cell 
wall binding domain from a different phage. The engineered protein was active against the clinical MRSA strain. Our results also underline the importance of cell wall binding domain not only in specific binding, but also in providing stability for the recombinant protein.

Author Contributions: Conceptualization, S.M.; methodology, S.M., M.A. and A.F.A.; software, S.M., M.A. and A.F.A.; validation, S.M. and M.A.; formal analysis, S.M., N.A., S.A.H. and B.F.A.-R.; investigation, S.M., M.A., N.A. and A.F.A.; resources, S.M.; data curation, S.M. and S.A.H.; writingoriginal draft preparation, S.M.; writing—review and editing, S.M.; visualization, S.M.; supervision, S.M.; project administration, S.M.; funding acquisition, S.M. All authors have read and agreed to the published version of the manuscript.

Funding: This work was supported by the National Plan for Science and Technology (NPST), Kingdom of Saudi Arabia by grant number: 15-BIO3608-02 awarded to S.M.

Institutional Review Board Statement: Not applicable.

Informed Consent Statement: Not applicable.

Data Availability Statement: The data presented in this study are available on reasonable request from the corresponding author.

Acknowledgments: The authors extend their appreciation to the National Plan for Science and Technology (NPST) at King Saud University, Riyadh, Kingdom of Saudi Arabia for funding this work through grant number: 15-BIO3608-02. The authors appreciate the efforts of Gautham Prasad (Class XB) and Ganga Prasad (Class XIIA) at Sabarigiri Residential School, Anchal, Kollam, Kerala, India for their help in data analysis from confocal microscopy. The authors would like to thank Udo Blaesi, Department of Microbiology and Immunobiology, MFPL, Vienna, Austria for the bacterial strains: $S$. aureus Rumba and bacteriophage $\$ 44 \mathrm{AHJD}$. The authors would also like to thank Andreas Peschel, Department of Infection Biology, Universität Tübingen, Germany for providing the bacterial strain S. aureus RN4220 and the phage $\phi 11$. We are grateful to the Confocal Microscopy unit at Central Laboratory, College of Science, King Saud University, Riyadh, Kingdom of Saudi Arabia.

Conflicts of Interest: The authors declare no conflict of interest.

\section{References}

1. Dams, D.; Briers, Y. Enzybiotics: Enzyme-Based Antibacterials as Therapeutics. Adv. Exp. Med. Biol. 2019, 1148, 233-253. [CrossRef]

2. Langdon, A.; Crook, N.; Dantas, G. The effects of antibiotics on the microbiome throughout development and alternative approaches for therapeutic modulation. Genome Med. 2016, 8, 39. [CrossRef]

3. Andrade, M.J.; Jayaprakash, C.; Bhat, S.; Evangelatos, N.; Brand, A.; Satyamoorthy, K. Antibiotics-Induced Obesity: A Mitochondrial Perspective. Public Health Genom. 2017, 20, 257-273. [CrossRef] [PubMed]

4. Shao, X.; Ding, X.; Wang, B.; Li, L.; An, X.; Yao, Q.; Song, R.; Zhang, J.A. Antibiotic Exposure in Early Life Increases Risk of Childhood Obesity: A Systematic Review and Meta-Analysis. Front. Endocrinol. 2017, 8, 170. [CrossRef]

5. Yuan, J.; Hu, Y.J.; Zheng, J.; Kim, J.H.; Sumerlin, T.; Chen, Y.; He, Y.; Zhang, C.; Tang, J.; Pan, Y.; et al. Long-term use of antibiotics and risk of type 2 diabetes in women: A prospective cohort study. Int. J. Epidemiol. 2020, 49, 1572-1581. [CrossRef]

6. Manoharadas, S.; Witte, A.; Bläsi, U. Antimicrobial activity of a chimeric enzybiotic towards Staphylococcus aureus. J. Biotechnol. 2009, 139, 118-123. [CrossRef]

7. Nelson, D.; Loomis, L.; Fischetti, V.A. Prevention and elimination of upper respiratory colonization of mice by group A streptococci by using a bacteriophage lytic enzyme. Proc. Natl. Acad. Sci. USA. 2001, 98, 4107-4112. [CrossRef]

8. Schmelcher, M.; Donovan, D.M.; Loessner, M.J. Bacteriophage endolysins as novel antimicrobials. Future Microbiol. 2012, 7, 1147-1171. [CrossRef]

9. Roach, D.; Donovan, D.M. Antimicrobial bacteriophage-derived proteins and therapeutic applications. Bacteriophage 2015, 5, e1062590. [CrossRef]

10. Gerstmans, H.; Criel, B.; Briers, Y. Synthetic biology of modular endolysins. Biotechnol. Adv. 2018, 36, 624-640. [CrossRef]

11. Vacek, L.; Kobzová, Š.; Čmelík, R.; Pantůček, R.; Janda, L. Enzybiotics LYSSTAPH-S and LYSDERM-S as Potential Therapeutic Agents for Chronic MRSA Wound Infections. Antibiotics 2020, 9, 519. [CrossRef]

12. Röhrig, C.; Huemer, M.; Lorgé, D.; Luterbacher, S.; Phothaworn, P.; Schefer, C.; Sobieraj, A.M.; Zinsli, L.V.; Mairpady Shambat, S.; Leimer, N.; et al. Targeting Hidden Pathogens: Cell-Penetrating Enzybiotics Eradicate Intracellular Drug-Resistant Staphylococcus aureus. mBio 2020, 11, e00209-20. [CrossRef] [PubMed]

13. Ramos-Vivas, J.; Elexpuru-Zabaleta, M.; Samano, M.L.; Barrera, A.P.; Forbes-Hernández, T.Y.; Giampieri, F.; Battino, M. Phages and Enzybiotics in Food Biopreservation. Molecules 2021, 26, 5138. [CrossRef] 
14. Lundén, J.; Björkroth, J.; Korkeala, H. Contamination Routes and Analysis in Food Processing Environments. In Handbook of Hygiene Control in the Food Industry; Lelieved, H.L.M., Holah, M.A., Eds.; Woodhead Publishing Series in Food Science, Technology and Nutrition; Woodhead Publishing: Cambridge, UK, 2005; pp. 539-555.

15. Alegbeleye, O.O.; Singleton, I.; Sant'Ana, A.S. Sources and Contamination Routes of Microbial Pathogens to Fresh Produce during Field Cultivation: A Review. Food Microbiol. 2018, 73, 177-208. [CrossRef]

16. Olaimat, A.N.; Holley, R.A. Factors Influencing the Microbial Safety of Fresh Produce: A Review. Food Microbiol. 2012, 32, 1-19. [CrossRef]

17. Sumrall, E.T.; Hofstee, M.I.; Arens, D.; Röhrig, C.; Baertl, S.; Gehweiler, D.; Schmelcher, M.; Loessner, M.J.; Zeiter, S.; Richards, R.G.; et al. An Enzybiotic Regimen for the Treatment of Methicillin-Resistant Staphylococcus aureus Orthopaedic Device-Related Infection. Antibiotics 2021, 10, 1186. [CrossRef]

18. Campoccia, D.; Montanaro, L.; Arciola, C.R. The significance of infection related to orthopedic devices and issues of antibiotic resistance. Biomaterials 2006, 27, 2331-2339. [CrossRef]

19. Arciola, C.R.; An, Y.H.; Campoccia, D.; Donati, M.E.; Montanaro, L. Etiology of implant orthopedic infections: A survey on 1027 clinical isolates. Int. J. Artif. Organs 2005, 28, 1091-1100. [CrossRef]

20. Masters, E.A.; Trombetta, R.P.; de Mesy Bentley, K.L.; Boyce, B.F.; Gill, A.L.; Gill, S.R.; Nishitani, K.; Ishikawa, M.; Morita, Y.; Ito, H.; et al. Evolving concepts in bone infection: Redefining "biofilm", "acute vs. chronic osteomyelitis", "the immune proteome" and "local antibiotic therapy". Bone Res. 2019, 7, 20. [CrossRef]

21. Costerton, J.W.; Post, J.C.; Ehrlich, G.D.; Hu, F.Z.; Kreft, R.; Nistico, L.; Kathju, S.; Stoodley, P.; Hall-Stoodley, L.; Maale, G.; et al. New methods for the detection of orthopedic and other biofilm infections. FEMS Immunol. Med. Microbiol. 2011, 61, 133-140. [CrossRef]

22. Sheehan, M.M.; Garcia, J.L.; Lopez, R.; Garcia, P. The lytic enzyme of the pneumococcal phage Dp-1: A chimeric lysin of intergeneric origin. Mol. Microbiol. 1997, 25, 717-725. [CrossRef] [PubMed]

23. Lukacik, P.; Barnard, T.J.; Keller, P.W.; Chaturvedi, K.S.; Seddiki, N.; Fairman, J.W.; Noinaj, N.; Kirby, T.L.; Henderson, J.P.; Steven, A.C.; et al. Structural engineering of a phage lysin that targets gram-negative pathogens. Proc. Natl. Acad. Sci. USA 2012, 109, 9857-9862. [CrossRef] [PubMed]

24. Briers, Y.; Walmagh, M.; Grymonprez, B.; Biebl, M.; Pirnay, J.P.; Defraine, V.; Michiels, J.; Cenens, W.; Aertsen, A.; Miller, S.; et al. Art-175 is a highly efficient antibacterial against multidrug-resistant strains and persisters of Pseudomonas aeruginosa. Antimicrob. Agents Chemother. 2014, 58, 3774-3784. [CrossRef]

25. Diaz, E.; Lopez, R.; Garcia, J.L. Chimeric phage-bacterial enzymes: A clue to the modular evolution of genes. Proc. Natl. Acad. Sci. USA 1990, 87, 8125-8129. [CrossRef]

26. Yang, H.; Yu, J.; Wei, H. Engineered bacteriophage lysins as novel anti-infectives. Front. Microbiol. 2014, 5, 542. [CrossRef] [PubMed]

27. São-José, C. Engineering of Phage-Derived Lytic Enzymes: Improving Their Potential as Antimicrobials. Antibiotics 2018, 7, 29. [CrossRef]

28. Anderson, B.; Rashid, M.H.; Carter, C.; Pasternack, G.; Rajanna, C.; Revazishvili, T.; Dean, T.; Senecal, A.; Sulakvelidze, A. Enumeration of bacteriophage particles: Comparative analysis of the traditional plaque assay and real-time QPCR- and nanosight-based assays. Bacteriophage 2011, 1, 86-93. [CrossRef]

29. Jakočiūnè, D.; Moodley, A.A. Rapid Bacteriophage DNA Extraction Method. Methods Protoc. 2018, 1, 27. [CrossRef] [PubMed]

30. Zhai, L.; Wu, L.; Li, F.; Burnham, R.S.; Pizarro, J.C.; Xu, B. A Rapid Method for Refolding Cell Surface Receptors and Ligands. Sci. Rep. 2016, 6, 26482. [CrossRef] [PubMed]

31. Manoharadas, S.; Altaf, M.; Alrefaei, A.W.F.; Devasia, R.M.; Hadj, A.Y.M.B.; Abuhasil, M.S. Concerted dispersion of Staphylococcus aureus biofilm by bacteriophage and 'green synthesized' silver nanoparticles. RSC Adv. 2021, 11, 1420-1429. [CrossRef]

32. Kelley, L.; Mezulis, S.; Yates, C.; Wass, M.; Sternberg, M. The Phyre2 web portal for protein modeling, prediction and analysis. Nat. Protoc. 2015, 10, 845-858. [CrossRef] [PubMed]

33. Takác, M.; Bläsi, U. Phage P68 virion-associated protein 17 displays activity against clinical isolates of Staphylococcus aureus. Antimicrob. Agents Chemother. 2005, 49, 2934-2940. [CrossRef]

34. Vázquez, R.; Blanco-Gañán, S.; Ruiz, S.; García, P. Mining of Gram-Negative Surface-Active Enzybiotic Candidates by SequenceBased Calculation of Physicochemical Properties. Front Microbiol. 2021, 12, 660403. [CrossRef]

35. Webber, M.A.; Piddock, L.J.V. The importance of efflux pumps in bacterial antibiotic resistance. J. Antimicrob. Chemother. 2003, 51, 9-11. [CrossRef]

36. Kusuma, C.; Jadanova, A.; Chanturiya, T.; Kokai-Kun, J.F. Lysostaphin-resistant variants of Staphylococcus aureus demonstrate reduced fitness in vitro and in vivo. Antimicrob Agents Chemother. 2007, 51, 475-482. [CrossRef] [PubMed]

37. Gilmer, D.B.; Schmitz, J.E.; Thandar, M.; Euler, C.W.; Fischetti, V.A. The Phage Lysin PlySs2 Decolonizes Streptococcus suis from Murine Intranasal Mucosa. PLoS ONE 2017, 12, e0169180.

38. Donovan, D.M.; Becker, S.C.; Dong, S.; Baker, J.R.; Foster-Frey, J.; Pritchard, D.G. Peptidoglycan hydrolase enzyme fusions for treating multi-drug resistant pathogens. Biotech. Int. 2009, 21, 6-10.

39. Son, B.; Yun, J.; Lim, J.A.; Shin, H.; Heu, S.; Ryu, S. Characterization of LysB4, an endolysin from the Bacillus cereus-infecting bacteriophage B4. BMC Microbiol. 2012, 12, 33. [CrossRef] [PubMed] 
40. Haddad, K.H.; Schmelcher, M.; Sabzalipoor, H.; Seyed, H.E.; Moniri, R. Recombinant endolysins as potential therapeutics against antibiotic-resistant Staphylococcus aureus: Current status of research and novel delivery strategies. Clin. Microbiol. Rev. 2018, 31, e00071-e00117.

41. Melo, L.D.R.; Brandao, A.; Akturk, E.; Santos, S.B.; Azeredo, J. Characterization of a new Staphylococcus aureus kayvirus harboring a lysin active against biofilms. Viruses 2018, 10, 182. [CrossRef] [PubMed]

42. Lowy, F.D. Staphylococcus aureus infections. N. Engl. J. Med. 1998, 339, 520-532. [CrossRef] [PubMed]

43. Ferry, T.; Perpoint, T.; Vandenesch, F.; Etienne, J. Virulence determinants in Staphylococcus aureus and their involvement in clinical syndromes. Curr. Infect. Dis. Rep. 2005, 7, 420-428. [CrossRef] [PubMed]

44. Kaur, J.; Singh, P.; Sharma, D.; Harjai, K.; Chhibber, S. A potent enzybiotic against methicillin-resistant Staphylococcus aureus. Virus Genes. 2020, 56, 480-497. [CrossRef] [PubMed]

45. Vybiral, D.; Takác, M.; Loessner, M.; Witte, A.; von Ahsen, U.; Bläsi, U. Complete nucleotide sequence and molecular characterization of two lytic Staphylococcus aureus phages: 44AHJD and P68. FEMS Microbiol. Lett. 2003, 219, 275-283. [CrossRef]

46. Whatmore, A.M.; Reed, R.H. Determination of turgor pressure in Bacillus subtilis: A possible role for K+ in turgor regulation. J. Gen. Microbiol. 1990, 136, 2521-2526. [CrossRef]

47. Doyle, R.J.; Marquis, R.E. Elastic, flexible peptidoglycan and bacterial cell wall properties. Trends Microbiol. 1994, 2, 57-60. [CrossRef]

48. Arnoldi, M.; Fritz, M.; Bauerlein, E.; Radmacher, M.; Sackmann, E.; Boulbitch, A. Bacterial turgor pressure can be measured by atomic force microscopy. Phys. Rev. E Stat. Phys. Plasmas Fluids Relat. Interdiscip. Topics 2000, 62, 1034-1044. [CrossRef] [PubMed]

49. Raz, A.; Serrano, A.; Lawson, C.; Thaker, M.; Alston, T.; Bournazos, S.; Ravetch, J.V.; Fischetti, V.A. Lysibodies are IgG Fc fusions with lysin binding domains targeting Staphylococcus aureus wall carbohydrates for effective phagocytosis. Proc. Natl. Acad. Sci. USA 2017, 114, 4781-4786. [CrossRef] [PubMed]

50. Schmelcher, M.; Tchang, V.S.; Loessner, M.J. Domain shuffling and module engineering of Listeria phage endolysins for enhanced lytic activity and binding affinity. Microb. Biotechnol. 2011, 4, 651-662. [CrossRef]

51. Daniel, A.; Euler, C.; Collin, M.; Chahales, P.; Gorelick, K.J.; Fischetti, V.A. Synergism between a novel chimeric lysin and oxacillin protects against infection by methicillin-resistant Staphylococcus aureus. Antimicrob. Agents Chemother. 2010, 54, 1603-1612. [CrossRef] [PubMed]

52. Pastagia, M.; Euler, C.; Chahales, P.; Fuentes-Duculan, J.; Krueger, J.G.; Fischetti, V.A. A novel chimeric lysin shows superiority to mupirocin for skin decolonization of methicillin-resistant and -sensitive Staphylococcus aureus strains. Antimicrob. Agents Chemother. 2011, 55, 738-744. [CrossRef] 